additional antigenic component of the Dane particle, which is known to have an outer coat and an inner core that are antigenically distinct. ${ }^{10}$ The e antigen is unlikely to be related to the core, since free core antigen has not been found in the serum of patients with either acute or chronic hepatitis-B virus infection. It is also unlikely to be related to $\mathrm{HBsAg}$, since it is smaller and not a lipoprotein. ${ }^{4}$ In our study the correlation between e antigen and Dane particles was not absolute, and the latter were detected, though infrequently, in sera positive for $\mathrm{e}$ antibody. In some preliminary studies examination of the $\mathrm{e}$ antigen-antibody precipitin lines obtained by immunodiffusion with the electron microscope has failed to detect Dane particles or any other aggregates, suggesting that $e$ is a non-particulate antigen. It therefore seems more likely that e antigen is a soluble product of hepatocytes infected with the hepatitis-B virus and is not related to the virus itself.
We are indebted to the Wellcome Trust for generous support.

\section{References}

${ }^{1}$ Levene, C, and Blumberg, B S, Nature, 1969, 221, 195.

${ }^{2}$ Le Bouvier, G L, Fournal of Infectious Diseases, 1971, 123, 671

${ }^{3}$ Magnius, L O, and Espmarck, J A, fournal of Immunology, 1972, 109, 1017.

4 Magnius, L O, Clinical and Experimental Immunology, 1975, 20, 209.

5 Nielsen, J O, Dietrichson, O, and Juhl, E, Lancet, 1974, 2, 913.

${ }^{6}$ De Groote, J, et al, Lancet, 1968, 2, 626.

Woolf, I L, et al, fournal of Clinical Pathology, 1974, 27, 348.

${ }^{8}$ Becker, M D, et al, Lancet, 1970, 1, 53.

9 Smith, M G M, Eddleston, A L W F, and Williams, R, Clinics in Gastroenterology, 1975, 4, 311 .

10 Almeida, J D, Rubinstein, D, and Stott, E J, Lancet, 1971, 2, 1225.

\title{
Does anaemia increase the risks to the fetus caused by smoking in pregnancy?
}

\author{
T G B DOW, P J ROONEY, MARION SPENCE
}

pregnant, and anaemic pregnant women, particularly as anaemia is still a relatively frequent complication of pregnancy.

\section{Summary}

A significantly greater rise in carboxyhaemoglobin concentration in response to smoking a single cigarette was shown in pregnant $(3.9 \%$ increase) as opposed to non-pregnant (2.1\% increase) women. This was more pronounced when anaemia was present $(5.0 \%$ increase) and appeared to be inversely related to the haemoglobin concentration. We suggest that the risks to the fetus may be particularly increased when anaemia complicates pregnancy in women who smoke cigarettes.

\section{Introduction}

The hazards to the fetus from maternal cigarette smoking after the fourth month of pregnancy are well known. ${ }^{1-3}$ The risks have been variously attributed to the different substances in cigarette smoke, although recently most attention has been centred on the carbon monoxide content, which raises the level of carboxyhaemoglobin $(\mathrm{COHb})$ in the blood of smokers who inhale to as much as $16 \% .{ }^{4}$ The rise in $\mathrm{COHb}$ concentration in response to smoking a single cigarette is greater in women than in men, ${ }^{5}$ this being attributed to the sex difference in haemoglobin concentration. This effect of haemoglobin may have special implications for those women who smoke in pregnancy and who are anaemic.

We have therefore compared the rise in $\mathrm{COHb}$ concentration after smoking a single cigarette in non-pregnant, normal

\footnotetext{
University Department of Obstetrics and Gynaecology, Glasgow Royal Maternity Hospital, Glasgow G4 0NA

T G B DOW, MB, MRCOG, senior registrar MARION SPENCE, research technician

Centre for Rheumatic Diseases, and University Department of Medicine, Glasgow Royal Infirmary, Glasgow

P J ROONEY, MB, MRCP, registrar
}

\section{Patients and methods}

Three groups of women were selected for the study. All were regular cigarette smokers. The first group consisted of 10 normal pregnant women late in the second trimester of pregnancy with haemoglobin levels of over $11 \mathrm{~g} / \mathrm{dl}$. The second group consisted of 10 women also late in the second trimester but whose haemoglobin was less than $10 \mathrm{~g} / \mathrm{dl}$. Apart from anaemia at the time of admission to the study these patients were normal. In each case the anaemia was characterised by a microcytic hypochromic blood film and associated with a low serum iron and normal serum vitamin $\mathbf{B}^{12}$ and folate levels. The third group consisted of 10 normal non-pregnant women with normal haemoglobin levels-that is, over $11 \mathrm{~g} / \mathrm{dl}$.

The change in $\mathrm{COHb}$ concentration was estimated spectrophotometrically ${ }^{6}$ in response to smoking the first cigarette of the morning, the women having rested for at least 30 minutes. A sample of venous blood was withdrawn before and two minutes after smoking the cigarette. The cigarettes were of a standard size and of a "non-mild" variety. In an effort to standardise the study the women were instructed to take a puff every 40 seconds, inhaling as deeply as possible to a total of 10 puffs.

\section{Results}

The initial COHb concentration in all instances was variable and bore no relationship to the daily cigarette consumption, and although the highest mean initial level was found in the normal, non-pregnant women, this group had the lowest mean consumption of cigarettes (see table).

In the non-pregnant group the mean rise in $\mathrm{COHb}$ concentration ( \pm SE of mean) was $2 \cdot 1 \pm 0 \cdot 2 \%$. A significantly greater increase was found in the normal pregnant group (mean rise $3.9 \pm 0.4 \% ; t=3.91$; $\mathrm{P}<0.005)$. The effect was more pronounced in the anaemic women, who had a mean rise of $5.0 \pm 0.2 \%(t=9.9 ; \mathrm{P}<0.0005)$. The difference in response between the normal pregnant and anaemic pregnant women was also significant $(t=2.53 ; \mathrm{P}<0.5)$. No correlation could be shown within each group between haemoglobin and percentage rise in $\mathrm{COHb}$ concentration, but when the three groups were taken as a whole a significant negative correlation was found $(r=-0.729$; $\mathrm{P}<0.001$ ). 
Changes in $\mathrm{COHb}$ levels in non-pregnant, pregnant, and anaemic pregnant women before and two minutes after smoking a single cigarette

\begin{tabular}{|c|c|c|c|c|c|c|c|c|c|}
\hline & & & & \multirow{2}{*}{$\underset{\text { (years) }}{\text { Age }}$} & \multirow{2}{*}{$\begin{array}{l}\text { Average cigarette } \\
\text { consumption/day }\end{array}$} & \multirow{2}{*}{$\underset{(\mathrm{g} / \mathrm{dl})}{\text { Haemoglobin }}$} & \multicolumn{3}{|c|}{ Blood COHb $(\%)$} \\
\hline & & & & & & & Before & After & Difference \\
\hline Normal pregnancy & .. & .. & . & $\begin{array}{l}22 \\
24 \\
21 \\
19 \\
25 \\
23 \\
28 \\
27 \\
28 \\
23\end{array}$ & $\begin{array}{l}20 \\
20 \\
20 \\
15 \\
40 \\
20 \\
15 \\
20 \\
20 \\
20\end{array}$ & $\begin{array}{l}11.9 \\
12.4 \\
12.1 \\
11.1 \\
12.6 \\
11.9 \\
13.1 \\
11.1 \\
12.0 \\
13.0\end{array}$ & $\begin{array}{l}1.2 \\
1.4 \\
1.5 \\
2.4 \\
3.6 \\
0.5 \\
2.0 \\
1.5 \\
1.0 \\
1.7\end{array}$ & $\begin{array}{l}7 \cdot 6 \\
4 \cdot 0 \\
5 \cdot 0 \\
6 \cdot 3 \\
5 \cdot 8 \\
6 \cdot 0 \\
6 \cdot 4 \\
5 \cdot 0 \\
4 \cdot 2 \\
5 \cdot 2\end{array}$ & $\begin{array}{l}6.4 \\
2.6 \\
3.5 \\
3.9 \\
2.2 \\
5.5 \\
4.4 \\
3.5 \\
3.2 \\
3.5\end{array}$ \\
\hline \multicolumn{4}{|c|}{ Mean \pm SE of mean } & $24 \cdot 0 \pm 0 \cdot 95$ & $21 \cdot 0 \pm 2 \cdot 2$ & $12 \cdot 1 \pm 0 \cdot 22$ & $1 \cdot 68 \pm 0 \cdot 27$ & $5.55 \pm 0.34$ & $3 \cdot 87 \pm 0.40$ \\
\hline Anaemic pregnancy & .. & .. & .. & $\begin{array}{l}24 \\
28 \\
26 \\
22 \\
25 \\
26 \\
30 \\
18 \\
22 \\
27\end{array}$ & $\begin{array}{l}15 \\
20 \\
20 \\
15 \\
25 \\
10 \\
20 \\
20 \\
20 \\
10\end{array}$ & $\begin{array}{l}8 \cdot 5 \\
9 \cdot 0 \\
9 \cdot 5 \\
8 \cdot 0 \\
9 \cdot 5 \\
9 \cdot 3 \\
8 \cdot 2 \\
8 \cdot 9 \\
8 \cdot 9 \\
9 \cdot 1\end{array}$ & $\begin{array}{l}1.2 \\
2.0 \\
1.8 \\
0.5 \\
3.2 \\
1.2 \\
1.6 \\
2.2 \\
1.6 \\
1.5\end{array}$ & $\begin{array}{l}6.5 \\
7.5 \\
7.5 \\
6.8 \\
7.4 \\
5.8 \\
6.0 \\
7.4 \\
6.4 \\
5.8\end{array}$ & $\begin{array}{l}5 \cdot 3 \\
5 \cdot 5 \\
5 \cdot 7 \\
6 \cdot 3 \\
4 \cdot 2 \\
4 \cdot 6 \\
4 \cdot 4 \\
5 \cdot 2 \\
4 \cdot 8 \\
4 \cdot 3\end{array}$ \\
\hline \multicolumn{4}{|c|}{ Mean $\pm \mathrm{SE}$ of mean } & $24 \cdot 8 \pm 1 \cdot 1$ & $17.5 \pm 1.53$ & $8.9 \pm 0.16$ & $1.68 \pm 0.22$ & $6 \cdot 7+0.22$ & $5 \cdot 0 \pm 0 \cdot 22$ \\
\hline Non-pregnant control & $\ldots$ & .. & . & $\begin{array}{l}23 \\
24 \\
24 \\
26 \\
22 \\
25 \\
23 \\
21 \\
26 \\
25\end{array}$ & $\begin{array}{l}20 \\
10 \\
10 \\
20 \\
15 \\
10 \\
20 \\
20 \\
15 \\
20\end{array}$ & $\begin{array}{l}12.8 \\
13.6 \\
14.9 \\
12.8 \\
1.36 \\
13.2 \\
13.8 \\
13.4 \\
12.8 \\
13.5\end{array}$ & $\begin{array}{l}1.5 \\
2.7 \\
1.8 \\
1.5 \\
2.4 \\
3.2 \\
2.2 \\
3.2 \\
1.9 \\
2.0\end{array}$ & $\begin{array}{l}3 \cdot 7 \\
4 \cdot 9 \\
4 \cdot 6 \\
3 \cdot 6 \\
3 \cdot 7 \\
4 \cdot 5 \\
4 \cdot 3 \\
4 \cdot 9 \\
3 \cdot 9 \\
5 \cdot 4\end{array}$ & $\begin{array}{l}2.2 \\
2.2 \\
2.8 \\
2.1 \\
1.3 \\
1.3 \\
2.1 \\
1.7 \\
2.0 \\
3.4\end{array}$ \\
\hline \multicolumn{4}{|c|}{ Mean $\pm S E$ of mean } & $23.9 \pm 0.53$ & $16 \cdot 0 \pm 1 \cdot 45$ & $13 \cdot 4 \pm 0 \cdot 2$ & $2 \cdot 24 \pm 0 \cdot 20$ & $4 \cdot 35 \pm 0 \cdot 19$ & $2 \cdot 11 \pm 0 \cdot 20$ \\
\hline
\end{tabular}

\section{Discussion}

These results show that the rise in $\mathrm{COHb}$ in response to a single cigarette is significantly greater in pregnant than in nonpregnant women and that a further significant increase is evident when iron-deficiency anaemia complicates pregnancy. As the mean haemoglobin concentration was greater in the nonpregnant than in the pregnant women it seems that the effect could well be a function of haemoglobin concentration. Certainly it does not relate to the number of cigarettes smoked daily or to the initial resting $\mathrm{COHb}$ concentration. Interestingly, the resting level of $\mathrm{COHb}$ was highest in the non-pregnant group, despite these women having the lowest daily consumption of cigarettes. This could relate to the distribution of carbon monoxide within the body pools of mother and fetus or to a faster rate of metabolism or excretion of carbon monoxide in pregnancy.

Though a statistically highly significant inverse relationship exists between haemoglobin concentration and the rise in $\mathrm{COHb}$ concentration, the relationship may not be direct and may depend on other haemodynamic factors that change in pregnancy and which may be exaggerated by anaemia, such as cardiac output and pulmonary blood flow.

The rise in the level of $\mathrm{COHb}$ after smoking a single cigarette is dependent on several factors, such as the type of cigarette smoked, the depth of inhalation, and the physical activity of the person at the time of study. Russell $e t a l^{5}$ showed that it was not related to the usual cigarette consumption or to the initial level of $\mathrm{COHb}$; a significant inverse relationship, however, was found between the haemoglobin concentration and the rise in $\mathrm{COHb}$. Our results confirm these findings. The relatively greater increase in $\mathrm{COHb}$ concentrations in the control women in our study in comparison with those recorded by Russell et $a l^{5}$ may have been due to the relatively longer period of abstinence from smoking before the study.

While the cause of the harmful effects of smoking in pregnancy is not fully understood, much attention has been given to the possible role of carbon monoxide. Ayres et $\mathrm{al}^{7}$ showed that low concentrations of carbon monoxide may have pronounced effects on cardiovascular function in normal people. The resultant hypoxaemic state described by these workers was considered by Brody and Coburn, ${ }^{8}$ who felt that it could be explained by changes in the oxyhaemoglobin dissociation curve.
Cole et $a l^{9}$ suggested that the shift to the left of the oxygen dissociation curve in response to carbon monoxide produces tissue anoxia in the fetus and showed that a COHb level of $20 \%$ was possible in the fetus. This was based on their observation that the umbilical cord $\mathrm{COHb}$ concentration was 1.8 times the maternal $\mathrm{COHb}$ concentration.

We suggest that the present data have particular implications for the fetus. It may be that although there is no evidence to suggest that higher daily levels of $\mathrm{COHb}$ are present in pregnancy, the distribution to the fetus gives a relatively lower maternal level of $\mathrm{COHb}$ once equilibration has taken place. When anaemia is present the relatively greater increase in maternal $\mathrm{COHb}$ levels after smoking could well mean that more carbon monoxide is passed on to the fetal pool of COHb. Thus the effects on the fetus of smoking in pregnancy could be increased. This enhanced response to cigarette smoking in pregnancy, and in anaemia of pregnancy in particular, gives support to the use of prophylactic iron, which raises the haemoglobin concentration in pregnancy, ${ }^{10}$ and suggests that the socalled physiological anaemia of pregnancy may place the fetus of a smoking mother at greater risk.

We thank Professor M C Macnaughton and the consultant staff of Glasgow Royal Maternity Hospital for allowing us to study their patients, and Miss Anne Kelly for her advice and technical help.

This study was supported by a grant from the board of management of Glasgow Royal Maternity Hospital.

\section{References}

1 Butler, N R, Goldstein, H, and Ross, E M, British Medical fournal, 1972 , 2,127

2 Butler, N R, and Goldstein, H, British Medical fournal, 1973, 4, 573.

${ }^{3}$ British Medical fournal, 1973, 1, 369.

4 Lawther, P J, and Commins, B T, Annals of the New York Academy of Sciences, 1970, 174, 135.

5 Russell, M A H, et al, Lancet, 1973, 2, 687.

${ }^{6}$ Commins, B T, and Lawther, P J, British fournal of Industrial Medicine, $1965,22,139$.

7 Ayres, S M, Gianelli, S, and Armstrong, R G, Science, 1965, 149, 193.

${ }^{8}$ Brody, J S, and Coburn, R F, Science, 1969, 164, 1297.

9 Cole, P V, Hawkins, L H, and Roberts, D, fournal of Obstetrics and Gynaecology of the British Commonwealth, 1972, 79, 782.

10 Scott, J M, Goldie, H, and Hay, S H, British Medical fournal, 1975, 1, 259. 